\title{
PEMANFAATAN MEDIA VIDEO UNTUK MENINGKATKAN HASIL BELAJAR PRAKTIK BERWUDHLU KELAS 2 SDN PRAMBON MADIUN
}

\author{
Insiyah $^{1)}$, Muhibuddin Fadhli ${ }^{2}$ \\ ${ }^{1}$ Guru Agama Islam SDN Prambon Dagangan Madiun \\ email: insiyah1961@gmail.com \\ ${ }^{2}$ PG-PAUD Universitas Muhammadiyah Ponorogo \\ email: muhibuddin.fadhli@gmail.com
}

\begin{abstract}
Instructional media is one of the important components in the learning process. Utilization can be very crucial in the learning process. Video is one type of audio-based learning media. One of the advantages of this media is that it can be rotated anytime and anywhere, so that students can independently utilize the media. The purpose of this research is to improve the learning result of the ablution practice which in practice there are still many mistakes. This study is action class research with two cycles. With minimum completeness criteria (KKM) 80 where the result of the first cycle of KKM students get an average of 75 and in the second cycle the average student learning outcomes score 85.
\end{abstract}

Keywords: Video, Learning Result, Ablution.

Abstrak: Media pembelajaran adalah salah satu komponen penting dalam proses pembelajaran. Pemanfaatannya bisa menjadi sangat krusial dalam proses pembelajaran. Media video adalah salah satu jenis media pembelajaran berbasis audio visual. Salah satu keunggulan media ini adalah dapat diputar kapan dan dimana saja, sehingga siswa dapat secara mandiri memanfaatkan media tersebut. Tujuan dari penelitian ini adalah untuk meningkatkan hasil belajar praktik berwudhlu yang dalam praktiknya masih banyak ditemui banyak kesalahan. Penelitian ini adalah peneltian tindakan kelas dengan dua siklus. Dengan KKM 80 dimana hasil dari siklus pertama KKM siswa memperoleh rata-rata 75 dan pada siklus kedua rata-rata hasil belajar siswa memperoleh nilai 85 .

Kata Kunci: Video, Hasil belajar, Berwudhu.

\section{PENDAHULUAN}

Pendidikan merupakan cara untuk memanusiakan manusia. Sebagai seorang yang terus berkembang dan bertumbuh manusia akan terus mendapat pendidikan baik dari tingkat dini hingga sampai pendidikan tinggi. Lebih lagi ketika berbicara tentang praktek berwudhu maka tidak akan bisa dijauhkan dari perspektif pendidikan Islam. "Pendidikan Islam dalam skala umum memberikan proses pendewasaan individu muslim/muslimah yang hendak mencapai tujuan kehidupan yang bahagia baik di dunia maupun di akhirat kelak. Pendidikan Islam pun dalam masa kini tidak ubahnya memiliki nilainilai normatif dan historis yang mendasarkan sumber ajaran agama Islam" (Muhammad Haris, 2015).

Komponen-komponen pendidikan Islam, yaitu: pengertian pendidikan Islam, dasar dan tujuan pendidikan Islam, kurikulum pendidikan Islam, metode pendidikan Islam, evaluasi pendidikan Islam dan lembaga pendidikan Islam, secara umum digagas dan dikemas yang merujuk pada nilai-nilai arajan agama Islam. Dari proses inilah maka manusia tadi 
akan menjadi pribadi yang siap untuk terjun dalam kehidupan yang sesungguhnya. Proses pembelajaran di sekolah memang dituntut untuk mengikuti proses dan selaras dengan berkembangya zaman. Proses tersebut tentunya harus senantiasa dikembangkan.

Salah satu cara untuk meningkatkan proses pembelajaran adalah dengan memanfaatkan media video. Media video adalah "an electronic medium for the recording, copying, playback, broadcasting, and display of moving visual" ("Video - HiDef Audio and Video," n.d.) media video adalah sebuah perangkat elektronik yang digunakan untuk merekam, memutar kemabli, dan dapat menampilka gambar bergerak. Menurut beberapa hasil penelitian media ini mampu untuk menstimulasi tumbuh kembang anak serta dapat meningkatkan hasil belajar.

$$
\text { Menurut Fadhli dalam }
$$
penelitiannya tentang pengembangan media video di sekolah dasar untuk materi IPS memberikan hasil bahwa media ini efektif dalam meningkatkan prestasi belajar IPS, ditunjukkan dengan "hasil uji-t diperoleh tobs $=2,98>$ ttabel $=2,024$, artinya bahwa kedua kelompok memiliki prestasi belajar yang berbeda atau tidak sama" (Fadhli, 2015). Selain itu menurut Gamoran media ini juga dapat membantu guru dalam proses pembelajaran dia berpendapat bahwa "Video clubs have the potential to support teacher learning inways that extend beyond the boundaries of the video clubmeetings themselves" (Gamoran Sherin \& van Es, 2009). Pendpat tersebut diamani oleh Zhang yang berpendapat bahwa "online video may be important to integrate interactive instructional video into $e$ learning systems"(Zhang, Zhou, Briggs, \& Nunamaker, 2006). Lebih khusus zhang memberikan sebuah gambaran bahwa keefektifan media ini juga berlaku dalam pembelajaran secara online atau e-learning.
Pembelajaran yang terjadi selama ini di SDN 2 Prrambon selama ini menggunakan buku teks, anak-anak diminta untuk melihat secara langsung gambargambar tersebut diamati dan anak-anak diminta untuk meniru gambar tersebut. Buku ini dinilai dapat membantu guru dalam proses pembelajaran namun kurang maksimal, salah satu keterbatasan buku adalah terbatasnya karakter dan mudah rusak, sehingga perlu adanya sebuah inovasi dalam proses pembelajaran selain memanfaatkan media ini. Pertimbangan inilah yang membuat penulis berani mengambil sebuah kesimpulan bahwa media video dapat digunakan dalam proses pembelajaran.

\section{METODE PENELITIAN}

Penelitian ini menggunakan penelitian tindakan kelas terdiri dari dua siklus, tiap siklus terdiri 4 tahapan yakni perencanaan, tindakan, observasi, dan refleksi. Pengambilan data menggunakan tes tertulis, wawancara dan observasi. Pada tiap siklus menggunakan 4 kali pertemuan dengan materi tentang materi berwudhu Wawancara dilakukan kepada guru, kepala sekolah dan siswa tentang pemanfaatan media video yang sudah bisa dengan mudah didapatkan di channel Youtube, peneliti menggunakan channel cutepriduction. Sedangkan observasi dilakukan dengan mengumpulkan dokumen foto, RPP, dan dokumen penunjang lainnya.

Analisis data menggunakan teknik analisis Miles \& Huberman, "mengemukakan bahwa aktivitas dalam analisis data kualitatif dilakukan secara interaktif dan berlangsung secara terus menerus sampai tuntas, sehingga datanya jenuh. Ukuran kejenuhan data ditandai dengan tidak diperolehnya lagi data atau informasi baru. Aktivitas dalam analisis meliputi reduksi data (data reduction), penyajian data (data display) serta 
Penarikan kesimpulan dan verifikasi (conclusion and verification)"(Schwandt, 1996).

Penelitian ini dilakukan pada siswa kelas 2 SDN Prambon Tahun Pelajaran 2016/2017 dengan jumlah siswa sebanyak 13 anak terdiri dari 5 anak laki-laki dan 8 anak perempuan. Waktu penelitian ini dilakukan pada semester genap tahun pelajaran 2016/2017 dari bulan Januari sampai dengan Mei.

\section{HASIL DAN PEMBAHASAN}

Dari deskripsi yang sudah disampaikan pada metode penelitian diatas bahwa penelitian ini menggunakan penelitian tindakan kelas. Dari hasil penelitian ditemukan beberapa temuan yang bisa menjadi pembahasan. Jalannya penelitian berlangsung kurang lebih selama 5 bulan terhitung dari bulan Januari-Mei, rentang waktu tersebut dianggap cukup untuk memberikan perlakuan dan untuk meningkatkan hasil belajar siswa. Pada siklus pertama peneliti menyiapkan rancangan dan instrument penelitian yang sudah di validasi sebelumnya, sehingga proses penelitian dapat berlajan dengan maksimal. Hasil dari siklus pertama menunjukkan bahwa ketika memasuki pertemuan ke-4 peneliti melakukan tes hasil belajar praktek berwudhlu dimana rata-rata hasil belajar yang diperoleh baru berada diangka 75, sedangkan indikator ketercapaian adalah 80. Sehingga dari hasil refleksi pada siklus pertama dipertimbangkan untuk dilanjutkan pada siklus kedua. Berikut tabel pemerolehan hasil belajar pada siklus pertama.

Tabel 1 dibawah menunjukkan rata-rata hasil belajar pada siklus pertama yang menunjukkan bahwa penelitian ini harus dilanjutkan pada siklus kedua.

Tabel 1. Hasil belajar siklus pertama

\begin{tabular}{l|c}
\hline Nama Siswa (Inisial) & Nilai \\
\hline $\mathrm{Aa}$ & 75 \\
\hline $\mathrm{Ab}$ & 80 \\
\hline $\mathrm{Ac}$ & 80 \\
\hline $\mathrm{Ad}$ & 80 \\
\hline $\mathrm{Ae}$ & 75 \\
\hline $\mathrm{Af}$ & 70 \\
\hline $\mathrm{Ag}$ & 70 \\
\hline $\mathrm{Ah}$ & 70 \\
\hline $\mathrm{Ai}$ & 75 \\
\hline $\mathrm{Aj}$ & 75 \\
\hline $\mathrm{Ak}$ & 75 \\
\hline $\mathrm{Al}$ & 75 \\
\hline Am & 75 \\
\hline $\mathrm{Rata}$-rata & 75 \\
\hline
\end{tabular}

Tabel 1 diatas memberikan sebuah refleksi dimana pada siklus kedua hal-hal yang harus diperbaiki adalah variasi penyampaian media video, peneliti mencoba untuk memberikan media ini secara kelompok, dengan berbantuan laptop. Rancangan penelitian juga menggunakan 4 kali pertemuan. Untuk menghindari repetisi maka sub-bab yang disampaikan juga berbeda.

Pada siklus kedua ini berfokus tentang bacaan sebelum dan sesudah, serta rukun wudhlu. Hasil penelitian pada siklus kedua menunjukkan hasil yang signifikan, dimana siswa sudah memperoleh ketuntasan minimal dengan rata-rata 85 , 
sehingga proses penelitian sudah dikatakan

berhasil dan dinyatakan selesai.

Tabel 2. Hasil belajar siklus kedua

\begin{tabular}{l|c}
\hline Nama siswa (inisial) & NIlai \\
\hline $\mathrm{Aa}$ & 80 \\
\hline $\mathrm{Ab}$ & 90 \\
\hline $\mathrm{Ac}$ & 85 \\
\hline $\mathrm{Ad}$ & 85 \\
\hline $\mathrm{Ae}$ & 85 \\
\hline $\mathrm{Af}$ & 85 \\
\hline $\mathrm{Ag}$ & 85 \\
\hline $\mathrm{Ah}$ & 85 \\
\hline $\mathrm{Ai}$ & 90 \\
\hline $\mathrm{Aj}$ & 85 \\
\hline $\mathrm{Ak}$ & 80 \\
\hline $\mathrm{Al}$ & 85 \\
\hline $\mathrm{Am}$ & 85 \\
\hline Rata-rata & 85 \\
\hline
\end{tabular}

Dari tabel 2 diatas peneliti menyimpulkan bahwa tindakan yang dilakukan pada penelitian ini dinhatakan berhasil. Peneliti juga melakukan triangulasi data untuk memastikan keakuratan serta kesahihan data yang diperoleh. Peneliti juga memberikan instrument wawancara kepada guru dan murid.

Dari hasil wawancara ditemukan beberapa fakta dimana, pertama; para guru menghendaki adanya inovasi dalam proses pembelajaran. Beberapa rekan guru di SDN Prambon menghendaki untuk diberikan beberapa materi media video selain praktek KESIMPULAN

Penelitian yang dilakukan ini mencoba untuk lebih mendekatkan siswa ke dunia nyata lewat media video. Sebelum mereka melakukan aktivitas berwudhlu, mereka diberi materi praktik berwudhlu dengan media video, sehingga ketika mereka melakukan dalam kondisi yang

\section{DAFTAR RUJUKAN}

Fadhli, M. (2015). Pengembangan Media Pembelajaran Berbasis Video Kelas IV Sekolah Dasar. Jurnal Dimensi Pendidikan Dan Pembelajaran, 3(1).

Gamoran Sherin, M., \& van Es, E. A. berwudhlu, utamanya materi-materi yang berhubungan dengan praktek atau sebuah proses seperti proses metamorphosis. Kedua, hasil wawancara dari siswa juga mengindikasikan bahwa terdapat kejenuhan dengan proses pembelajaran yang diulangulang tanpa adanya kreasi, lewat media video ini siswa lebih termotivasi untuk mengikuti proses pembelajaran.

Dari hasil triangulasi data diatas menunjukkan bahwa terdapat kesinergisan antara hasil tindakan serta fakta antara hasil wawancara dan hasil belajar.

nyata, para siswa tidak merasa kesulitan dan melakukan dnegan baik dan benar.

Hasil penelitian ini menunjukkan bahwa media video efektif untuk meningkatkan hasil belajar praktik berwudhlu, sehingga perlu adanya kajiankajain yang berfokus dalam pemanfaatan media video dalam proses pembelajaran.

(2009). Effects of Video Club Participation on Teachers' Professional Vision. Journal of Teacher Education, 60(1), 20-37. https://doi.org/10.1177/002248710832 8155 
Muhammad Haris. (2015). Pendidikan Islam dalam Perspektif Prof. H.M Arifin. Ummul Quro, 6 (Jurnal Ummul Qura Vol VI, No 2, September 2015), 1-19. Retrieved from

http://ejournal.kopertais4.or.id/index.p $\mathrm{hp} /$ qura/issue/view/531

Schwandt, T. (1996). Qualitative data analysis: An expanded sourcebook edited by Matthew B. Miles and A. Michael Huberman. Thousand Oaks, Calif.: Sage, 1994. Evaluation and Program Planning, 19, 106-107. https://doi.org/10.1016/0149-

7189(96)88232-2

Video - HiDef Audio and Video. (n.d.). Hidefnj.com. Retrieved from http://hidefnj.com/video.html

Zhang, D., Zhou, L., Briggs, R. O., \& Nunamaker, J. F. (2006). Instructional video in e-learning: Assessing the impact of interactive video on learning effectiveness. Information and Management, 43(1), 15-27. https://doi.org/10.1016/j.im.2005.01.0 04 
50 JURNAL PENDIDIKAN EDUTAMA, Vol 5, No. 1, Januari 2018 